\title{
Purification and biochemical characterization of pectinase produced by Aspergillus fumigatus isolated from soil of decomposing plant materials
}

\author{
Raphael Emuebie Okonji ${ }^{1}$, Babamotemi Oluwasola Itakorode ${ }^{2 *}$ Julius Ovie Ovumedia ${ }^{1}$ and Odunayo Selimot Adedeji ${ }^{3}$ \\ ${ }^{1}$ Department of Biochemistry and Molecular Biology, Faculty of Science, Obafemi Awolowo University, Ile-Ife, Osun State, Nigeria, ${ }^{2}$ Department of Chemical \\ Sciences (Biochemistry Unit), Oduduwa University Ipetumodu, Ile-Ife, Nigeria, ${ }^{3}$ Department of Biochemistry, Faculty of Science, Federal University Oye Ekiti, \\ Ekiti State, Nigeria
}

\begin{tabular}{|c|c|}
\hline ARTICLE INFO & ABSTRACT \\
\hline $\begin{array}{l}\text { Article history: } \\
\text { Received on: October } 03,2018 \\
\text { Accepted on: November } 30,2018 \\
\text { Available online: April } 05,2019\end{array}$ & $\begin{array}{l}\text { This study isolated, screened, and identified a pectinase-producing fungus from a decomposing plant material. It } \\
\text { also cultured the isolated fungus under optimized conditions to obtain crude pectinase enzyme as well as purified } \\
\text { and investigated the biochemical characteristics of the purified enzyme. The fungal strain was isolated on pectinase } \\
\text { screening agar medium containing } 1 \% \text { pectin and obtained a clear zone. It was identified as Aspergillus fumigatus and }\end{array}$ \\
\hline $\begin{array}{l}\text { Key words: } \\
\text { Pectinase, } \\
\text { purification, } \\
\text { Aspergillus fumigatus, } \\
\text { Isolate }\end{array}$ & $\begin{array}{l}\text { cultivated for enzyme production using banana, plantain, and orange peels as the solid substrate. Under optimized } \\
\text { conditions, a maximum of } 3.52 \mathrm{U} / \mathrm{ml} \text { pectinase activity was obtained at } 65 \% \text { moisture content after } 144 \mathrm{~h} \text { ( } 6 \text { days) } \\
\text { of incubation period on orange peel, } 1.5 \mathrm{ml} \text { inoculum, and } 3 \% \text { salt content. A. fumigatus pectinase was purified } \\
4.45 \text {-fold and a yield of } 26.16 \% \text { with a specific activity of } 38.88 \mathrm{U} / \mathrm{mg} \text {. The molecular weight determined on sodium } \\
\text { dodecyl sulfate (SDS-PAGE) was } 31.6 \mathrm{kDa} \text {. The pectinase exhibited maximum activity at } 60^{\circ} \mathrm{C} \text {, optimum pH of } 5.0 \text {, } \\
\text { and stability at } 40-50^{\circ} \mathrm{C} \text {. The enzyme showed a preference for polygalacturonic acid as its primary substrate with a } \\
K_{\mathrm{M}} 3.08 \mathrm{mg} / \mathrm{ml} \text { and } \mathrm{V}_{\max } \text { of } 1.61 \mathrm{U} / \mathrm{ml} \text {. The enzyme was activated by } 0.5 \mathrm{mM} \mathrm{Na}, \mathrm{K}^{+} \text {, and } 1-5 \% \text { toluene. The enzyme } \\
\text { activity was inhibited by metal cations; } 20 \% \text { ethanol, } 4.0 \mathrm{mM} \mathrm{SDS,} \mathrm{and} \mathrm{L-cysteine.} \mathrm{The} \mathrm{obtained} \mathrm{results} \mathrm{showed} \mathrm{that} \\
\text { A. fumigatus pectinase could be a candidate for potential industrial and biotechnological application. }\end{array}$ \\
\hline
\end{tabular}

\section{INTRODUCTION}

The use of enzyme technology to meet various human needs is becoming popular. Enzymes are used extensively in industry to improve the production of fruit juices, fruits texture, and enzymatic peeling of fruits [1-3]. It has been used in the textile industry as well as coffee and tea fermentation $[4,5]$. Pectinases are enzymes that are responsible for the biological degradation of pectin, a large molecular weight polysaccharide found in plants [6,7]. One of the most important processes in biomass degradation is the biological decomposition of pectin $[8,9]$. In plants, pectinases play a diverse role such as cell-tocell adhesion, a source of signaling molecules, and in the ripening of fruits [10]. Pectinases are also important in plant pathogenesis and have been reported to be the first enzyme synthesized by certain fungal and bacterial pathogens grown on isolated plant cell walls so as to "prepare" the cell wall components for subsequent degradation by other enzymes [11]. Pectinases are also important industrial enzymes used in the production of fruit juices and wines [5,12]. Vegetable oil extraction can

\section{*Corresponding Author:}

Babamotemi Oluwasola Itakorode, Department of Chemical Sciences, Biochemistry Unit, Oduduwa University Ipetumodu, Ile-Ife, Nigeria.

E-mail: itakorgsoli@yahoo.com be augmented by applying enzymes such as pectinase [5]. Pectinases are secreted by a wide range of microorganisms such as bacteria and fungi $[13,14]$ and it accounts for $25 \%$ of the global food enzyme sales [5]. The microorganisms that are used for the production of commercially important enzymes such as pectinases must be "generally regarded as safe" and able to secrete the enzyme in large quantities to the extracellular environment for easy extraction of the enzyme [15]. The preference for a microbial source is usually due to the low cost of production, enzyme content is more predictable and controllable, availability of raw materials for production, and mass production without ethical clearance [16]. The cost of production can be reduced by optimizing the enzyme production conditions [17]. The high cost of the production, as well as the stability of pectinases in an industrial process, is conceivably the major constraint in the commercialization of the new sources of pectinase. Given the biotechnological potential of pectinolytic enzymes, microbial production of pectinases has been extensively studied in recent years [5,17-19]. Thus, the study of physicochemical properties of pectinase produced by Aspergillus fumigatus may help in the development of products which will intervene in plants diseases caused by pectinase-secreting pathogen organisms and also help in eliminating the use of carcinogenic organic solvents in industrial processes. 


\section{MATERIALS AND METHODS}

\subsection{Collection of Samples}

Agro wastes such as orange peels, banana peels, and plantain peels were collected from local market and dumpsite in Omole Estate, IleIfe. The wastes were oven dried for $36 \mathrm{~h}$ at $80^{\circ} \mathrm{C}$, pulverized, and stored in an airtight container. The pulverized samples were mixed with soil and left to decay in a container for several weeks. Soil samples around the decomposing peels were collected in sterile bottles and taken to the laboratory for analysis.

\subsection{Isolation of Fungi and Screening for Pectinase Production}

About $1 \mathrm{~g}$ of the collected soil sample was serially diluted and $1 \mathrm{ml}$ of the diluted sample was taken into sterilized Petri plates. Agar solution was then poured into the plates using the pour plate method, allowed to set, and incubated at $37^{\circ} \mathrm{C}$ for $72 \mathrm{~h}$. The cultures were subsequently subcultured until pure isolates were obtained. The screening for pectinase production was done using pectin agar plate [20]. Briefly, pure cultures were inoculated into sterilized and solidified pectin agar medium. Inoculated plates were incubated at $37^{\circ} \mathrm{C}$ for $48 \mathrm{~h}$. Thereafter, the plates were flooded with iodinepotassium iodide solutions for 5-10 $\mathrm{min}$ and pectinase-producing colonies were detected by the appearance of a clear zone around them. The fungi isolate with the highest value of the clear zone of the hydrolysis of pectinase was selected and stored in the fridge on pectin agar.

\subsection{Identification of the Pectinase-producing Isolate}

The selected fungus with the highest value of pectinase hydrolysis was macromorphologically characterized by observing colony characteristics such as color, texture, and spore structure according to the handbook for the identification of fungi [21] and micromorphologically by employing conventional lactophenol cotton blue technique (LPCB).

\subsection{Pectinase Production using Solid State Fermentation}

About $10 \mathrm{~g}$ of solid substrates, consisting of $99.7 \%(9.97 \mathrm{~g})$ each of the powdered plant peels, $0.1 \%(0.01 \mathrm{~g})(\mathrm{NH} 4)_{2} \mathrm{SO}_{4}, 0.1 \% \mathrm{MgSO}_{4}$, and $0.1 \% \mathrm{~K}_{2} \mathrm{HPO}_{4}$, were weighed into $250 \mathrm{ml}$ Erlenmeyer's flasks and then autoclaved at $121^{\circ} \mathrm{C}$ for $20 \mathrm{~min}$. After cooling, $1 \mathrm{ml}$ of the standard inoculum was introduced and the final moisture content adjusted to $70 \%$ using distilled water. The flasks were incubated for 14 days at $37^{\circ} \mathrm{C}$. Following fermentation, $60 \mathrm{ml}$ of citrate buffer (0.1 M, pH 5.0) was added to the flasks and stirred for $30 \mathrm{~min}$ under ice. The mixture was filtered and centrifuged at $12,000 \mathrm{rpm}$ for $20 \mathrm{~min}$. The resulting supernatant was tested for pectinase activity.

\subsection{Pectinase Assay Method}

The enzyme activity was determined using pectin as a substrate. The assay mixture consists of $0.80 \mathrm{ml}$ of the substrate solution $(1.0 \% \mathrm{w} / \mathrm{v}$ citric pectin in $0.1 \mathrm{M}$ citric buffer $\mathrm{pH} 5.0$ ) and $0.20 \mathrm{ml}$ of enzyme solution. The reaction medium was incubated at $50^{\circ} \mathrm{C}$ for $20 \mathrm{~min}$ and terminated by the addition of $1.5 \mathrm{ml}$ of 3, 5-dinitrosalicylic acid reagent [22]. The absorbance of the reaction medium was taken at $540 \mathrm{~nm}$. One unit of pectinase activity (U) was defined as $1 \mu \mathrm{mol}$ reducing sugar released per minute using galacturonic acid as standard.

\subsection{Protein Concentration Determination}

The protein concentration was estimated by the method of Bradford [23]. Bovine serum albumin (BSA) was used as standard.

\subsection{Optimization of Pectinase Production}

The step-wise optimization of pectinase produced by the isolate was studied for four optimization parameters: Incubation time, moisture content, the volume of inoculum, and $\left(\mathrm{NH}_{4}\right)_{2} \mathrm{SO}_{4}$ salt concentration.

\subsubsection{Effect of incubation time, ammonium salt concentration, and moisture content on pectinase production}

Production medium was prepared into seven $250 \mathrm{ml}$ flasks, at intervals of $48 \mathrm{~h}$ up to 14 days, a flask was taken and the crude enzyme extracted for enzyme activity and protein concentration [24]. Powdered orange peel was used as the solid substrate. The moisture content was adjusted from 40 to $80 \%$ at $5 \%$ interval while the inoculum volume was varied from $0.5 \mathrm{ml}$ to $4.0 \mathrm{ml}$. After 6 days, the crude enzyme was extracted and checked for enzyme activity. The effect of ammonium salt concentration was checked by varying $\left(\mathrm{NH}_{4}\right)_{2} \mathrm{SO}_{4}$ salt from $0.1 \%$ to $4.0 \%$.

\subsection{Purification Procedure}

\subsubsection{Pectinase purification on CM-Sephadex C-50 and Sephacryl $S-200$}

Crude pectinase produced was subjected to $80 \%$ ammonium sulfate saturation and left overnight in the refrigerator. The resulting precipitate was dissolved in a small volume of $0.1 \mathrm{M}$ citrate buffer ( $\mathrm{pH}$ 5.0) and dialyzed extensively in cold $0.1 \mathrm{M}$ citrate buffer ( $\mathrm{pH} 5.0$ ). $5 \mathrm{ml}$ of the concentrated enzyme was layered on CM-Sephadex C-50 column equilibrated with $0.1 \mathrm{M}$ citrate buffer ( $\mathrm{pH}$ 5.0). Fractions were collected at a rate of $15 \mathrm{ml} / \mathrm{h}$. Unbound protein was removed by citrate buffer (0.1 M, pH 5.0) followed by a step-wise elution with $0.5 \mathrm{M}$ and $1.0 \mathrm{M} \mathrm{NaC} 1$ in the buffer. Pectinase activity and protein concentration of the fractions were determined. The active fractions were pooled and dialyzed against $50 \%$ glycerol in $0.1 \mathrm{M}$ citrate buffer, $\mathrm{pH} 5.0 .5 \mathrm{ml}$ of the concentrated enzyme was layered on a Sephacryl S-200 column. The column was eluted with $0.1 \mathrm{M}$ citrate buffer, $\mathrm{pH} 5.0$ at the flow rate of $20 \mathrm{ml} / \mathrm{h}$. Pectinase activity was checked while protein concentration was monitored spectrophotometrically at $280 \mathrm{~nm}$.

\subsubsection{Native molecular weight determination}

The native molecular weight was determined on Sephacryl S-200 column $(1.5 \mathrm{~cm} \times 65.5 \mathrm{~cm})$. The standard proteins were lysozyme (14,000 Da; $15 \mathrm{mg} / \mathrm{ml})$, trypsin $(24,000 \mathrm{Da} ; 10 \mathrm{mg} / \mathrm{ml})$, pepsin $(35,000 \mathrm{Da} ; 10 \mathrm{mg} / \mathrm{ml})$, ovalbumin $(45,000 \mathrm{Da} ; 10 \mathrm{mg} / \mathrm{ml})$, and BSA $(66,000 ; 10 \mathrm{mg} / \mathrm{ml})$. Fractions of $5.0 \mathrm{ml}$ were collected and monitored spectrophotometrically and the elution volume of each protein was estimated. Void volume $\left(\mathrm{V}_{0}\right)$ was determined using blue dextran $(2 \mathrm{mg} / \mathrm{ml})$. The pure enzyme $(5.0 \mathrm{ml})$ was then passed through the same column and the elution volume of the pectinase was estimated. The method of Laemmli [25] was used to determine the subunit molecular weight.

\subsection{Characterization of the Enzyme}

\subsubsection{Kinetic parameter determination}

The kinetic parameters $\left(\mathrm{V}_{\max }\right.$ and $\left.K_{\mathrm{M}}\right)$ of the enzyme were determined for three substrates: $67 \%$ methoxylated citric pectin, $7.8 \%$ methoxylated apple pectin, and polygalacturonic acid (PGA). The concentrations were varied from 1 to $8 \mathrm{mg} / \mathrm{ml}$ and the initial reaction velocities were determined. The data were plotted according to the method of Lineweaver and Burk [26].

\subsubsection{Effect of Temperature and $\mathrm{pH}$}

The optimum temperature of the enzyme was assayed using the method of Tari et al. at temperatures between $30^{\circ} \mathrm{C}$ and $90^{\circ} \mathrm{C}$. Citric pectin was 
used as the substrate. Effect of $\mathrm{pH}$ was studied using citrate buffer (4.0-5.0), phosphate buffer (6.0-8.0), and borate buffer (9.0-10.0). Citric pectin was used as substrate.

\subsubsection{Thermal Stability of A. fumigatus Pectinase Activity}

The enzyme was pre-incubated in a $0.1 \mathrm{M}$ citrate buffer within a temperature range of $40-70^{\circ} \mathrm{C}$. For a time span of $120 \mathrm{~min}$ at intervals of $15 \mathrm{~min}$, aliquots of enzyme samples were withdrawn and the residual activity was determined.

\subsubsection{Effect of Salts on A. fumigatus Pectinase Activity}

Influence of various salts at a different concentration on the enzyme activity was checked. The tested salts were $\mathrm{NaCl}, \mathrm{KCl}, \mathrm{NH}_{4} \mathrm{Cl}$, $\mathrm{SnCl}_{2}, \mathrm{CaCl}_{2}, \mathrm{BaCl}_{2}, \mathrm{MnCl}_{2}, \mathrm{MgCl}_{2}$, and $\mathrm{AlCl}_{3}$. The enzyme was preincubated for $10 \mathrm{~min}$ at $60^{\circ} \mathrm{C}$ with the various salts, before the addition of pectin; then, the residual pectinase activity was evaluated. Assay mixture without salts was taken as control.

\subsubsection{Effect of organic solvents on A. fumigatus pectinase activity} Pectinase assay was performed in the presence of $1 \%, 5 \%, 10 \%$, and $20 \%$ of various organic solvents. The organic solvents used include hexane, methanol, ethanol, acetone, toluene, and diethyl ether (DEE). The enzyme activity was checked as previously described.

\subsubsection{Inhibition of pectinase activity}

The effects of known enzyme inhibitors such as ethylenediaminetetraacetic acid (EDTA), beta-mercaptoethanol (BME), Triton X-100, sodium dodecyl sulfate (SDS) and Tween-80, and L-cysteine on the pectinase activity were studied. The enzyme was pre-incubated with $0.5 \mathrm{mM}$ and $1.0 \mathrm{mM}, 2.0 \mathrm{mM}, 3.0 \mathrm{mM}$, and $4.0 \mathrm{mM}$ of these inhibitors before the addition of substrate. Reactions in the absence of these inhibitors were used as the control with $100 \%$ enzyme activity. All chemicals were solubilized in distilled water.

\section{RESULTS AND DISCUSSION}

\subsection{Isolation, Screening, and Optimization of $A$. fumigatus}

This study made an attempt to isolate the fungus capable of producing pectinase, from the soil of decomposing plant materials. Among all the isolates, A. fumigatus showed the maximum pectinase activity based on carbohydrase hydrolysis of pectin in pectin-agar plate assay. A. fumigatus was identified based on microscopic and macroscopic examinations on LPCB. A. fumigatus is a saprophytic fungus that is found widespread in nature. This organism has been found to reproduce not only asexually but also has a functional cycle of sexual reproductive [27]. Furthermore, the fungus can grow at a temperature range of $37-50^{\circ} \mathrm{C}[28]$.

The clear zone of hydrolysis around the selected strain is shown in Figure 1. When subjected to pectinase production, orange peel produced the highest pectinase activity as well as total protein concentration (Figure 2). Maximum pectinase activity $(1.75 \mathrm{U} / \mathrm{ml})$ was observed at 6 days of incubation with a steady decline of activity after 6 days (Figure 3a). The best moisture content for A. fumigatus (65\%) produced a pectinase activity of $2.3 \mathrm{U} / \mathrm{ml}$ (Figure $3 \mathrm{~b}$ ). Furthermore, highest pectinase production was also observed at $1.5 \mathrm{ml}$ inoculum volume (Figure $3 \mathrm{c}$ ) and $3 \%$ salt concentration (Figure 3d), respectively. Similar observations on the orange peel as an excellent carbon source for pectinase production have been reported $[29,30]$. The reason for the highest pectinase activity using orange peel as solid substrate could be the high percentage of pectin found in the cell wall of the peel. Several

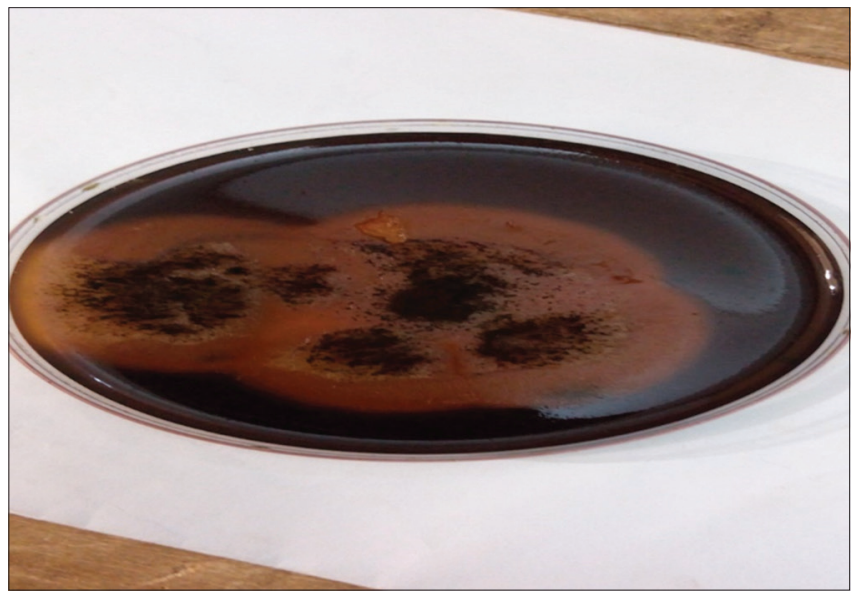

Figure 1: Screening of fungi for pectinase activity

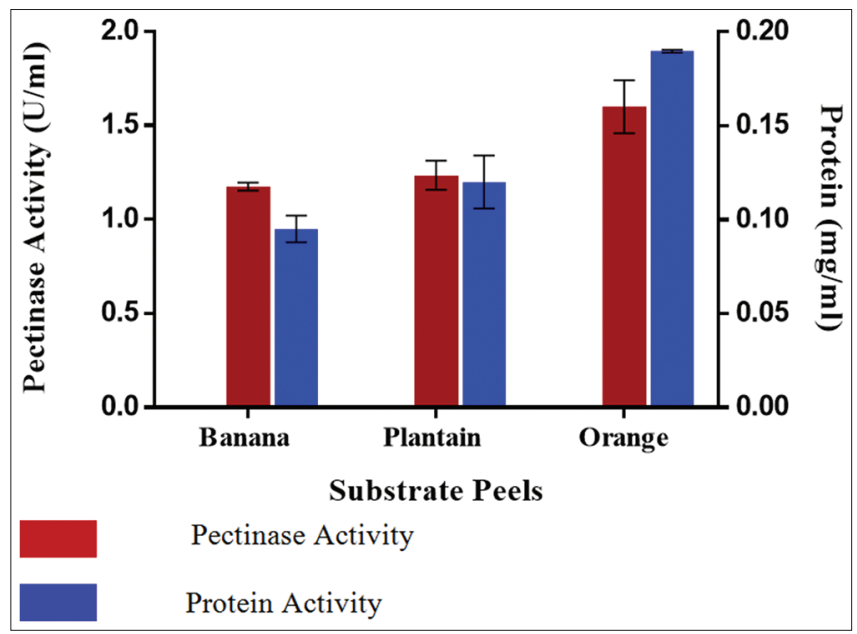

Figure 2: Pectinase activities and protein concentrations using different solid substrate

works have been carried out to show that pectinolytic fungi produce pectinase maximally between 3 and 6 days incubation period. The ideal substrate humidity for pectinase production by Aspergillus foetidus was reported to be between $80 \%$ and $90 \%$.

\subsection{Purification of $A$. fumigatus Pectinase}

A. fumigatus pectinase was purified with a fold of 4.45 , a yield of $26.14 \%$, and specific activity of $38.88 \mathrm{U} / \mathrm{mg}$ of protein (Table 1 ). The elution profiles after CM Sephadex C-50 ion-exchange chromatography and Sephacryl S-200 are shown in Figure 4 and 5, respectively. The molecular weight of native and denatured pectinase was determined using the marker proteins lysozyme ( $14.5 \mathrm{kDa})$, trypsin $(24 \mathrm{kDa})$, pepsin (35 kDa), ovalbumin (45 kDa), and BSA $(66 \mathrm{kDa})$ to be about $32.5 \mathrm{kDa}$ by gel filtration and SDS PAGE, respectively, indicating that the enzyme is of monomer in nature (Figure 6). Microbial pectinases have been reported to be monomeric in structure and generally fall within the size range of 30-70 $\mathrm{kDa}$ [31-35]. Two endopolygalacturonases PGI and PGII purified from $A$. japonicas showed the molecular weight of 38 and $65 \mathrm{kDa}$, respectively [36]. Polygalacturonase isolated from A. awomori showed a molecular weight of $41 \mathrm{kDa}$ [37]. Furthermore, pectinase isolated from Bacillus licheniformis showed a molecular weight of $38 \mathrm{kDa}$ [38]. 
Table 1: Summary of the purification process for Aspergillus fumigatus pectinase

\begin{tabular}{lccccc} 
Purification step & Total protein $(\mathbf{m g})$ & Total activity $(\mathbf{U})$ & Specific activity (U/mg) & Yield (\%) & Purification fold \\
Crude sample & 21.63 & 188.74 & 8.73 & 100.00 & 1.00 \\
$0-80 \%\left(\mathrm{NH}_{4}\right)_{2} \mathrm{SO}_{4}$ precipitation & 12.29 & 128.53 & 10.66 & 68.09 & 1.22 \\
Ion-exchange chromatography & 3.40 & 51.64 & 15.19 & 27.36 \\
Sephacryl-200 gel filtration & 1.21 & 49.38 & 38.88 & 26.16 & 4.74 \\
\hline
\end{tabular}
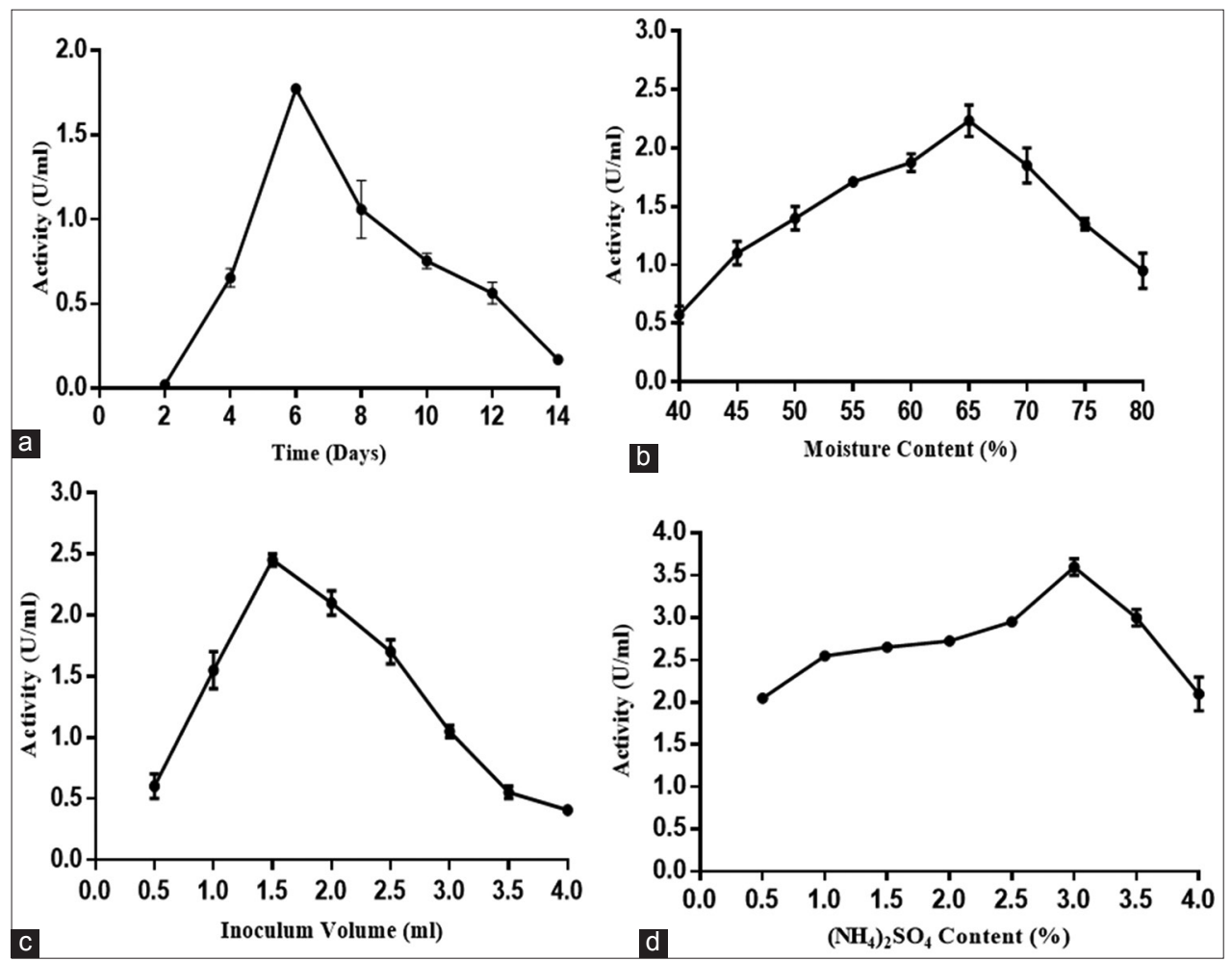

Figure 3: Effect of optimization parameters on Aspergillus fumigatus pectinase production. (a) Effect of incubation time on the pectinase production, (b) effect of moisture content on the pectinase production at 6 days of the incubation, (c) effect of inoculum volume on pectinase production at 6 days of incubation period and $65 \%$ moisture content, (d) effect of ammonium sulfate concentration at 6 days incubation period, $65 \%$ moisture content, and $1.5 \mathrm{ml}$ inoculum.

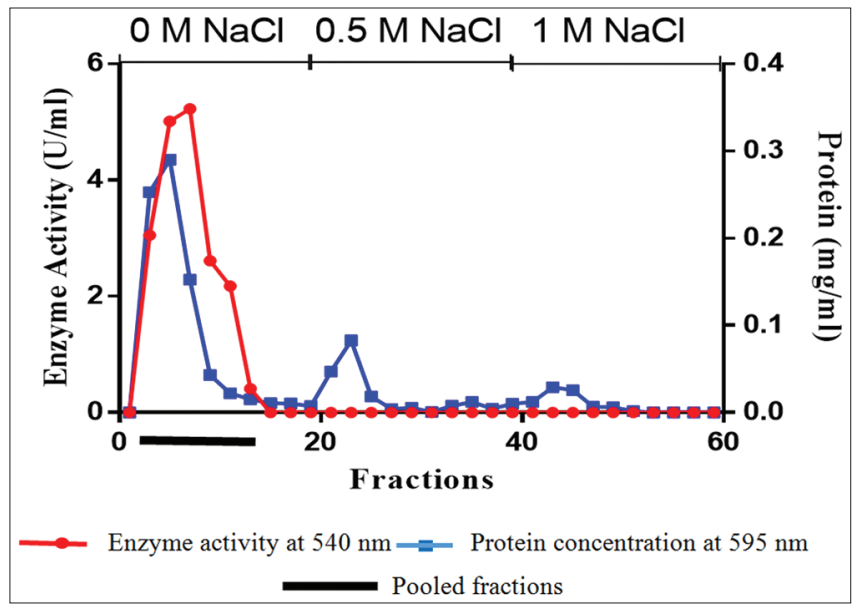

Figure 4: CM-Sephadex C-50 ion-exchange chromatography.

\subsection{Kinetic Parameters of $A$. fumigatus Pectinase}

The kinetic parameters $\left(K_{\mathrm{m}}\right.$ and Vmax) of $A$. fumigatus pectinase for citrus pectin, apple pectin, and PGA as substrate are 7.11, 6.01, and
$3.08 \mathrm{mg} / \mathrm{ml}$, respectively. Kinetic data are summarized in Table 2. $A$. fumigatus has a higher affinity for PGA. Several $K_{\mathrm{M}}$ values in the range of $1-9 \mathrm{mg} / \mathrm{ml}$ have been reported for polygalacturonases [39-48]. Exo-polygalacturonase from Penicillium frequentans was shown to have a $K_{\mathrm{M}}$ of $1.6 \mathrm{mg} / \mathrm{ml}$ [41]. A value of $0.22 \mathrm{mg} / \mathrm{ml}$ was reported for Rhizomucor pusillus pectinase using PGA as substrate [42]. It can be said that the kinetic parameters of pectinases vary with the enzyme source and nature substrate used for the assay. In most cases, the $K_{\mathrm{M}}$ value is low, which is in agreement with the result of the present study.

\subsection{Effect of $\mathrm{pH}$ and Temperature on $A$. fumigatus Pectinase Activity}

A. fumigatus pectinase activity was optimum at $60^{\circ} \mathrm{C}$ as shown in Figure 7. The thermal stability of the pectinase showed that at $60^{\circ} \mathrm{C}$, the enzyme retained $100 \%$ activity for $45 \mathrm{~min}$ and losing about $50 \%$ activity at the end of $120 \mathrm{~min}$ of incubation (Figure 8). Similar results were obtained for pectinase from other sources [9,43], as well as from Aspergillus spp. [5]. These results indicate that for industrial application of the pectinase from A. fumigatus, the suitable temperature range could be $40-50{ }^{\circ} \mathrm{C}$. A. fumigatus pectinase has an optimum $\mathrm{pH}$ at 5.0 and decreases significantly below and above this value (Figure 9). 


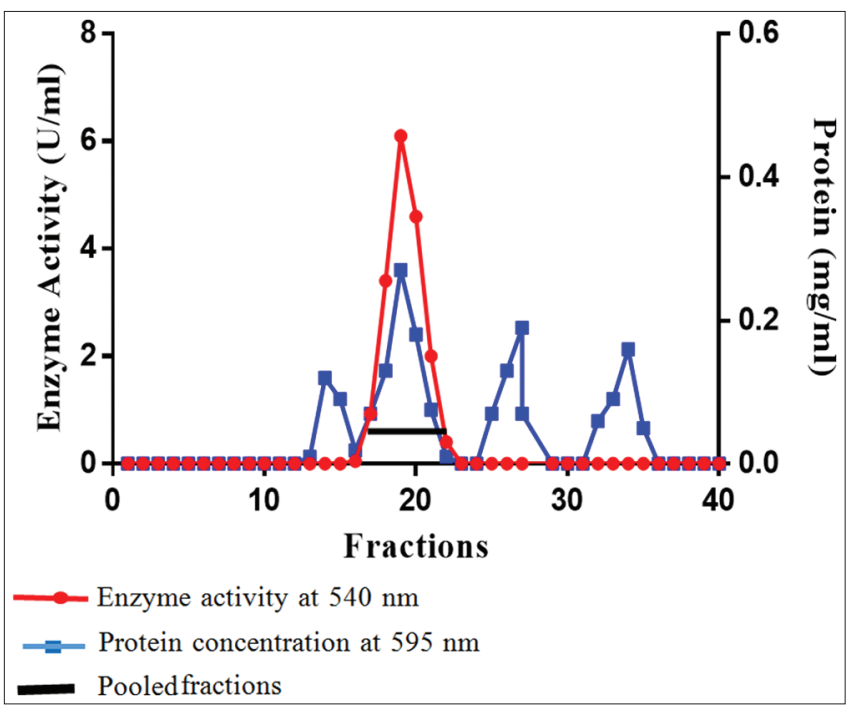

Fig. 5: Sephacryl S-200 gel filtration chromatography.

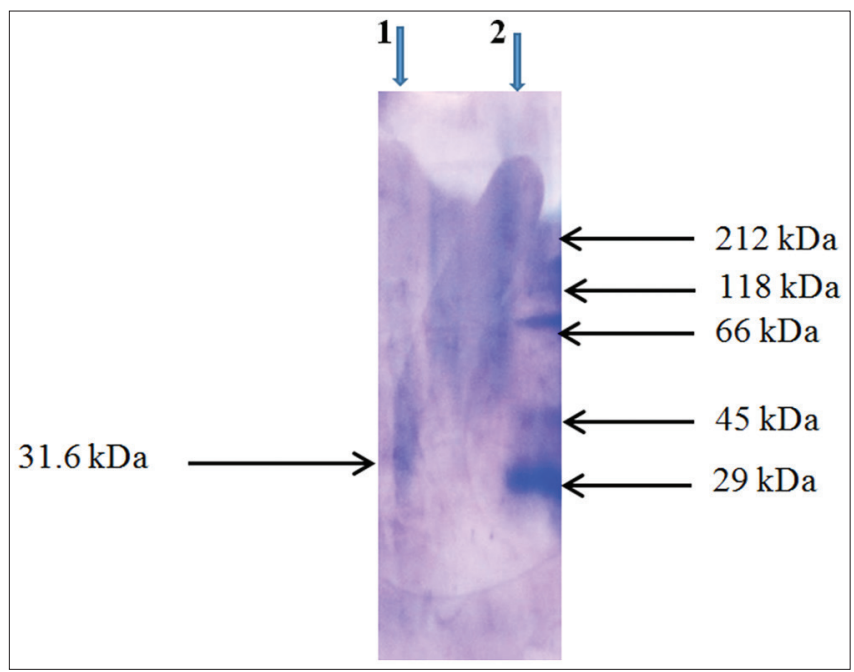

Figure 6: Electropherogram of SDS-PAGE of Aspergillus fumigatus pectinase. Lane 1 is A. fumigatus pectinase while Lane 2 is the molecular weight ladder

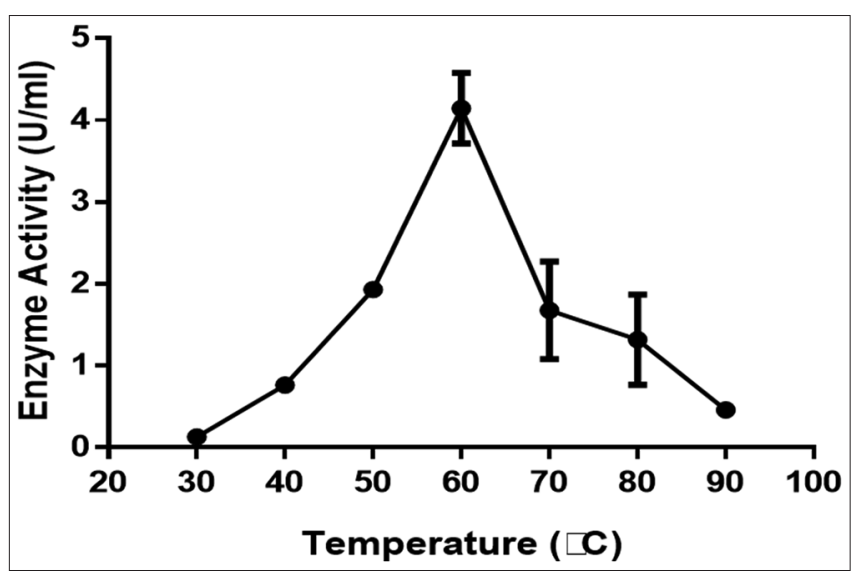

Figure 7: Effect of temperature on the activity of Aspergillus fumigatus pectinase

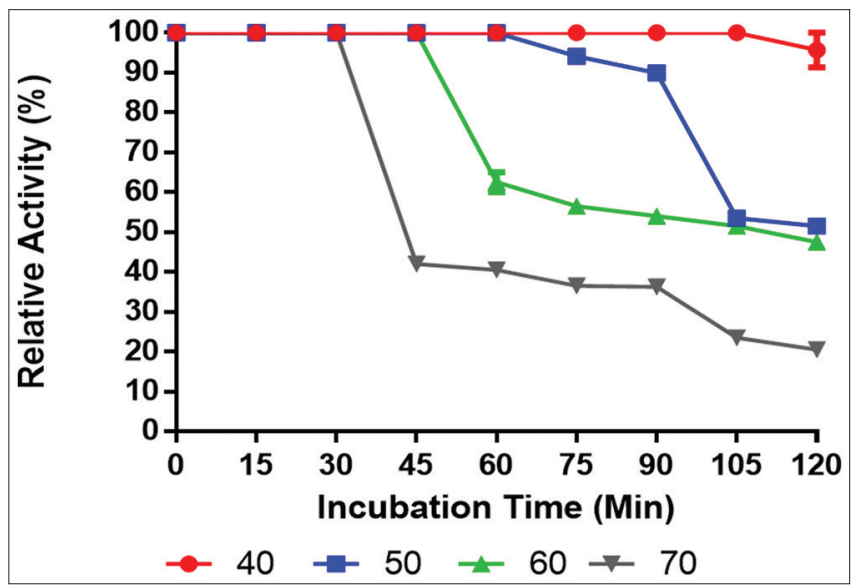

Figure 8: Thermal stability of Aspergillus fumigatus pectinase activity

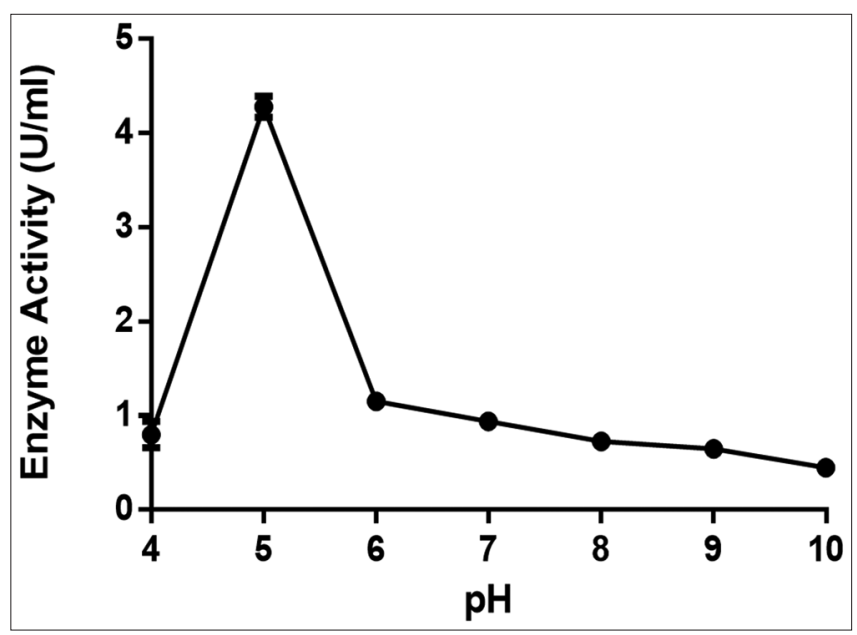

Figure 9: Effect of $\mathrm{pH}$ on the pectinase activity of Aspergillus fumigatus activity

Similar results have been reported from previous work on Aspergillus spp. [5]. Acidic pectinases are produced generally by fungi, especially Aspergillus spp. [44]. Therefore, A. fumigatus pectinase can be one of the candidates of acid pectinases, which can be employed in the extraction of pectin in fruit juices, in winemaking, and in maceration of vegetables.

The values shown represent the average of duplicate experiments. Error bars represent the standard deviation.

\subsection{Effect of Salts, Organic Solvents, and Inhibitors on A. fumigatus Pectinase Activity}

Table 3 presents the effect of monovalent, bivalent, and trivalent chloride salts on A. fumigatus pectinase. The result shows that the pectinase activity increased significantly by the monovalent ions but decreases by divalent ions and the trivalent ion. Activation of the pectinolytic enzyme has been reported [45]. This increase in the enzyme activity may be due to charge neutralization by $\mathrm{Na}^{+}, \mathrm{K}^{+}$, and $\mathrm{NH}_{4}^{+}$on the pectin polymer [12], so as to reduce the repulsion between the pectin and the overall negative charge of the enzyme. Inhibition by all salt of divalent cations such as $\mathrm{CaCl}_{2}$ and $\mathrm{MgCl}_{2}$ may be due to either the formation of homogalacturonan chain cross-link by the $\mathrm{Ca}^{2+}$ and $\mathrm{Mg}^{2+}$ cation [46]; thus, decreasing the 
availability of the substrate to the enzyme or the binding of the cations to an amino acid side chain involved in the binding or catalysis of the substrate.

The influence of various organic solvents on A. fumigatus pectinase activity is shown in Table 4. Hexane, toluene, and DEE with low $\varepsilon$ values of $1.9,2.4$, and 4.3 , respectively, increase the pectinase activity. This increase in activity is more significant (approximately 35\%) with hexane than with other non-polar solvents. The increase in pectinase

Table 2: Kinetic parameters of the Aspergillus fumigatus purified pectinase

\begin{tabular}{lcc} 
Substrate & $\boldsymbol{K}_{\mathbf{M}}(\mathbf{m g} / \mathbf{m l})$ & $\mathbf{V}_{\max }(\mu \mathrm{mol} / \mathbf{m i n} / \mathbf{m l})$ \\
PGA & 3.08 & 1.61 \\
Apple pectin & 6.10 & 3.39 \\
Citrus pectin & 7.11 & 4.24 \\
\hline
\end{tabular}

PGA: Polygalacturonic acid

Table 3: The effect of salts on Aspergillus fumigatus pectinase activity

\begin{tabular}{lccc}
\hline Residual activity (\%) & $\mathbf{0 . 1} \mathbf{~ m M}$ & $\mathbf{0 . 5} \mathbf{~ m M}$ & $\mathbf{1} \mathbf{~ m M}$ \\
Control & 100.00 & 100.00 & 100.00 \\
$\mathrm{NaCl}$ & $178.48 \pm 5.21$ & $203.80 \pm 10.76$ & $135.87 \pm 7.93$ \\
$\mathrm{KCl}$ & $154.01 \pm 3.56$ & $195.78 \pm 6.17$ & $145.15 \pm 2.99$ \\
$\mathrm{NH}_{4} \mathrm{Cl}$ & $162.02 \pm 4.99$ & $185.48 \pm 9.66$ & $127.51 \pm 8.27$ \\
$\mathrm{CaCl}_{2}$ & $96.62 \pm 2.44$ & $24.89 \pm 1.43$ & $8.44 \pm 1.01$ \\
$\mathrm{BaCl}_{2}$ & $91.14 \pm 5.87$ & $54.43 \pm 7.13$ & $6.33 \pm 0.56$ \\
$\mathrm{HgCl}_{2}$ & $94.51 \pm 3.11$ & $89.03 \pm 5.20$ & $19.83 \pm 1.39$ \\
$\mathrm{MgCl}_{2}$ & $92.68 \pm 1.65$ & $68.01 \pm 1.91$ & $23.33 \pm 2.18$ \\
$\mathrm{MnCl}_{2}$ & $89.65 \pm 5.52$ & $55.34 \pm 3.89$ & $16.01 \pm 0.90$ \\
$\mathrm{SnCl}_{2}$ & $98.66 \pm 0.91$ & $76.98 \pm 2.09$ & $56.11 \pm 4.41$ \\
$\mathrm{AlCl}_{3}$ & $89.16 \pm 1.92$ & $74.23 \pm 5.60$ & $59.71 \pm 3.77$ \\
\hline
\end{tabular}

Table 4: Effect of organic solvents on Aspergillus fumigatus pectinase activity

\begin{tabular}{lcccc}
$\begin{array}{l}\text { Residual } \\
\text { activity (\%) }\end{array}$ & $\mathbf{1 \%}$ & $\mathbf{5 \%}$ & $\mathbf{1 0 \%}$ & $\mathbf{2 0 \%}$ \\
Control & 100.00 & 100.00 & 100.00 & 100.00 \\
Hexane & $134.64 \pm 2.13$ & $138.64 \pm 3.40$ & $135.20 \pm 4.92$ & $136.31 \pm 1.35$ \\
Toluene & $115.08 \pm 1.56$ & $115.58 \pm 1.23$ & $106.53 \pm 0.71$ & $96.98 \pm 1.51$ \\
DEE & $106.98 \pm 1.05$ & $105.99 \pm 0.75$ & $101.73 \pm 0.23$ & $92.46 \pm 0.65$ \\
Acetone & $95.98 \pm 2.70$ & $94.18 \pm 1.70$ & $96.36 \pm 0.71$ & $93.47 \pm 3.26$ \\
Ethanol & $96.65 \pm 1.06$ & $94.41 \pm 1.98$ & $90.50 \pm 2.92$ & $58.66 \pm 5.24$ \\
Methanol & $91.06 \pm 0.65$ & $88.27 \pm 1.34$ & $87.71 \pm 4.34$ & $35.20 \pm 3.13$ \\
\hline
\end{tabular}

activity by the non-polar organic solvents may be due to the increase in the concentration of the substrate pectin in the aqueous environment due to the insolubility of pectin in the non-polar organic solvent; thus, making the pectin more available for enzyme action [47]. On the other hand, the polar solvents acetone, ethanol, and methanol with $\varepsilon$ values of 21, 25, and 33 respectively, decrease the pectinase activity of A. fumigatus. This decrease is more significant with ethanol and methanol at $20 \%$ solvent concentration. Therefore, A. fumigatus pectinase can be a potential candidate in winemaking where the alcohol percentage is $<10 \%$ or even between $10 \%$ and $15 \%$ alcohol concentrations. A similar result on the inhibitory effect of ethanol, which is an important product in the winemaking, has been shown by Merin et al. [48].

Influence of various inhibitors on A. fumigatus pectinase activity is presented in Table 5. The effect of inhibitors on enzyme activity can provide important information on the primary and secondary structure of the protein. SDS, Tween-80, and L-cysteine affect the pectinase activity significantly at $4.0 \mathrm{mM}$ inhibitor concentration. The effect of BME on the activity was insignificant for all the concentrations studied $(0.5-4.0 \mathrm{mM})$. BME reduces disulfide bonds and can act as a biological antioxidant. This result suggests that there is no vulnerable disulfide bond holding the structure of the pectinase together, meaning that the pectinase from A. fumigatus is a monomeric enzyme as already confirmed by the calculations made from the native and subunit molecular weights. The decrease $(10-13 \%)$ in the pectinase activity by EDTA is constant from 0.5 to $4.0 \mathrm{mM}$. This suggests that EDTA decreases the pectinase activity by means other than chelating the pectinase enzymes together. Therefore, A. fumigatus pectinase is not a metalloenzyme. However, the stimulatory and inhibitory effect of EDTA on Penicillium oxalicum polygalacturonase has been reported $[49,50]$. The effect of EDTA also suggests that $A$. fumigatus pectinase is not a polymethylgalacturonate lyase, which requires $\mathrm{Ca}^{2+}$ and is strongly inhibited by EDTA [5]. SDS, Tween-80, and L-cysteine which are known enzyme inhibitors also strongly inhibited the pectinase from A. fumigatus at higher concentrations.

\section{CONCLUSION}

The pectinase from Aspergillus fumigatus exhibited some desirable properties that could be utilized in industrial processes. The optimum temperature, thermal stability, $\mathrm{pH}$, substrate specificity in the presence of metal ions, and non-aqueous organic solvents make pectinase from the isolate a potential candidate for application in industrial processes. On the other hand, more researches would be needed to find out the type of pectinase from A. fumigatus and also establish the mechanism of action of the pectinase.

Table 5: Effect of inhibitors on Aspergillus fumigatus pectinase activity

\begin{tabular}{|c|c|c|c|c|c|}
\hline Residual activity (\%) & $0.5 \mathrm{mM}$ & $1.0 \mathrm{mM}$ & $2.0 \mathrm{mM}$ & $3.0 \mathrm{mM}$ & $4.0 \mathrm{mM}$ \\
\hline Control & 100.00 & 100.00 & 100.00 & 100.00 & 100.00 \\
\hline $\mathrm{BME}$ & $99.59 \pm 1.23$ & $99.56 \pm 0.98$ & $99.58 \pm 1.21$ & $99.54 \pm 1.05$ & $99.17 \pm 0.48$ \\
\hline EDTA & $90.50 \pm 2.42$ & $86.36 \pm 1.54$ & $86.78 \pm 1.71$ & $88.02 \pm 6.29$ & $86.78 \pm 4.04$ \\
\hline Triton X-100 & $83.47 \pm 3.26$ & $82.75 \pm 1.45$ & $81.36 \pm 2.14$ & $80.17 \pm 3.91$ & $80.58 \pm 1.98$ \\
\hline SDS & $87.19 \pm 4.32$ & $61.57 \pm 3.71$ & $47.52 \pm 0.33$ & $46.69 \pm 1.53$ & $45.87 \pm 0.75$ \\
\hline Tween-80 & $96.24 \pm 2.11$ & $69.83 \pm 3.98$ & $39.67 \pm 0.67$ & $38.84 \pm 0.16$ & $38.02 \pm 0.12$ \\
\hline L-cysteine & $80.03 \pm 5.04$ & $79.34 \pm 2.43$ & $78.06 \pm 3.13$ & $55.37 \pm 4.10$ & $34.30 \pm 0.75$ \\
\hline
\end{tabular}




\section{REFERENCES}

1. Pandey A, Soccol CR, Rodriguez-Leon JA, Nigam P. Solid-State Fermentation in Biotechnology. New Delhi: Asia Tech Publishers, Inc.; 2001. p. 200-21.

2. Gupta R, Beg QK, Khan S, Chauhan B. An overview on fermentation, downstream processing and properties of microbial alkaline proteases. Appl Microbiol Biotechnol 2002;60:381-95.

3. Tochi BN, Wang Z, Xu SY, Zhang W. The influence of pectinase and pectinase/hemicellulases enzyme preparations on percentage pineapple juice recovery, particulates and sensory attributes. Pak J Nutr 2009;8:1184-9.

4. Kobayashi T, Higaki N, Yajima N, Suzumatsu A, Hagihara H, Kawai S, et al. Purification and properties of a galacturonic acidreleasing exopolygalacturonase from a strain of Bacillus. Biosci Biotechnol Biochem 2001;65:842-7.

5. Jayani RS, Saxena S, Gupta R. Microbial pectinolytic enzymes: A review. Process Biochem 2005;40:2931-44.

6. Joshi VK, Attri D. Solid state fermentation of apple pomace for the production of value added products. Nat Prod Radiance 2006;5:289-96.

7. Maria de Lourdes TM, Polizeli J, Terenzi HF. Pectinase production by Neurospora crassa: Purification and biochemical characterization of extracellular polygalacturonase activity. J Gen Microbiol 1991;137:1815-23.

8. Fernando TH, Jayasinghe CK, Wijesundera RL. Cell wall degrading enzyme secretion by Colletotrichum acutatum the causative fungus of secondary leaf fall of Hevea brasiliensis (rubber). Mycol Res 2001;105:195-201.

9. Yadav S, Yadav PK, Yadav D, Yadav KD. Purification and characterization of pectin lyase produced by Aspergillus terricola and its application in retting of natural fibers. Appl Biochem Biotechnol 2009; 159:270-83.

10. Khan M, Nakkeeran E, Umesh-Kumar S. Potential application of pectinase in developing functional foods. Annu Rev Food Sci Technol 2013;4:21-34.

11. De Lorenzo G, D’Ovidio R, Cervone F. The role of polygalacturonaseinhibiting proteins (PGIPs) in defense against pathogenic fungi. Annu Rev Phytopathol 2001;39:313-35.

12. Alkorta I, Gabirsu C, Lhama MJ, Serra JL. Industrial applications of pectic enzymes: A review. Process Biochem 1998;33:21-8.

13. Angayarkanni J, Palaniswamy M, Murugesan S, Swaminathan K. Improvement of tea leaves fermentation with Aspergillus Spp. Pectinase. J Biosci Bioeng 2002;94:299-303.

14. Rasheedha AB, Kalpana MD, Gnanaprabhal GR, Pradeep BV, Palaniswamy M. Production and characterization of pectinase enzyme from Penicillium chrysogenum. Indian J Sci Technol 2010;3:377-81.

15. Matti L, Jouni J, Ossi P, Ossi T, Hans ES. Industrial use of enzymes. Physiol Maint 2009;2:???.

16. Murad HA, Saleem MM. Utilization of permeate for producing exopolysaccharides from lactic acid bacteria. Mansoura Univ J Agric Sci 2001;26:2167-75.

17. Hoondal GS, Tiwari RP, Tewari R, Dahiya N, Beg QK. Microbial alkaline pectinases and their industrial applications: A review. Appl Microbiol Biotechnol 2002;59:409-18.

18. Kashyap DR, Vohra PK, Chopra S, Tewari R. Applications of pectinases in the commercial sector: A review. Bioresour Technol 2001;77:215-27.

19. Gummadi SN, Panda T. Purification and biochemical properties of microbial pectinases. A review. Process Biochem 2003;38:987-96.

20. Kasana RC, Salwan R, Dhar H, Dutt S, Gulati A. A rapid and easy method for the detection of microbial cellulases on agar plates using gram's iodine. Curr Microbiol 2008;57:503-7.

21. Alexopoulos CJ, Mims CW, Blackwell M. Introductory Mycology.
Vol. 4. New York: Wiley; 1996.

22. Wang G, Michailides TJ, Bostock RM. Improved detection of polygalacturonase activity due to Mucor piriformis with a modified dinitrosalicylic acid reagent. Phytopathology 1997;87:161-3.

23. Bradford MM. A rapid and sensitive method for the quantitation of microgram quantities of protein utilizing the principle of protein-dye binding. Anal Biochem 1976;72:248-54.

24. Silva D, Martins ES, Da Silva R, Gomes E. Pectinase production by Penicillium viridicatum RFC3 by solid state fermentation using agricultural wastes and agro-industrial by-products. Braz J Microbiol 2002;33:318-24.

25. Laemmli UK. Cleavage of structural proteins during the assembly of the head of bacteriophage T4. Nature 1970;227:680-5.

26. Lineweaver H, Burk D. The determination of enzyme dissociation constants. J Am Chem Soc 1934;56:658-66.

27. O'Gorman CM, Fuller H, Dyer PS. Discovery of a sexual cycle in the opportunistic fungal pathogen Aspergillus fumigatus. Nature 2009;457:471-4.

28. Abad A, Fernández-Molina JV, Bikandi J, Ramírez A, Margareto J, Sendino J, et al. What makes Aspergillus fumigatus a successful pathogen? Genes and molecules involved in invasive aspergillosis. Rev Iberoam Micol 2010;27:155-82.

29. Giese EC, Dekker RF, Barbosa AM. Orange bagasse as substrate for the production of pectinase and laccase by Botryosphaeria rhodina mamb-05 in submerged and solid state fermentation. BioResources 2008;3:335-45.

30. Ahmed SA, Mostafa FA. Utilization of orange bagasse and molokhia stalk for production of pectinase enzyme. Braz J Chem Eng 2013;30:449-56.

31. Cho SW, Lee S, Shin W. The X-ray structure of Aspergillus aculeatus polygalacturonase and a modeled structure of the polygalacturonaseoctagalacturonate complex. J Mol Biol 2001;311:863-78.

32. Schols HA, Visser RG, Voragen AG. Pectin and Pectinase. The Netherlands: Wageningen Academic Press; 2009. p. 101-35.

33. Klug-Santner BG, Schnitzhofer W, Vrsanská M, Weber J, Agrawal PB, Nierstrasz VA, et al. Purification and characterization of a new bioscouring pectate lyase from Bacillus pumilus BK2. J Biotechnol 2006;121:390-401.

34. Tari C, Dogan N, Gogus N. Biochemical and thermal characterization of crude exo-polygalacturonase produced by Aspergillus sojae. Food Chem 2008;111:824-9.

35. Banu AR, Kalpana MD, Gnanaprabhal GR, Pradeep BV, Palaniswamy M. Production and characterization of pectinase enzyme from Penicillium chrysogenum. Indian J Sci Technol 2010;3:377-81.

36. Hasunuma T, Fukusaki E, Kobayashi A. Methanol production is enhanced by expression of an Aspergillus niger pectin methylesterase in tobacco cells. J Biotechnol 2003;106:45-52.

37. Nagai M, Katsuragi T, Terashita T, Yoshikawa K, Sakai T. Purification and characterization of an endo-polygalacturonase. From Aspergillus awamori. Biosci Biotechnol Biochem 2000;64:1729-32.

38. Madu JO, Okonji RE, Torimir, N, Agboola FK. Purification and characterization of pectinase from Bacillus licheniformis obtained from a cassava waste dump. J Adv Biol 2016;8:1685-95.

39. Saad N, Briand M, Gardarin C, Briand Y, Michaud P. Production, purification and characterization of an endopolygalacturonase from Mucor rouxii NRRL 1894. Enzyme Microb Technol 2007;41:800-5.

40. Corredig M, Kerr W, Wicker L. Separation of thermostable pectinmethylesterase from marsh grapefruit pulp. J Agric Food Chem 2000;48:4918-23.

41. Favey S, Bourson C, Bertheau Y, Kotoujansky A, Boccara M. Purification of the acidic pectate lyase and nucleotide sequence of the corresponding gene (pelA) of Erwinia chrysanthemi strain 3937. J Gen Microbiol 1992;138:499-508.

42. Siddiqui MA, Pande V, Arif M. Production, purification, 
and characterization of polygalacturonase from Rhizomucor pusillus isolated from decomposting orange peels. Enzyme Res 2012;2012:138634.

43. Phutela U, Dhuna V, Sandhu S, Chadha BS. Pectinase and polygalacturonase production by a thermophilic Aspergillus fumigatus isolated from decomposing orange peels. Braz J Microbiol 2005;36:63-9.

44. Pedrolli DB, Monteiro AC, Gomes E, Carmonal EC. Pectin and pectinases: Production, characterization and industrial application of microbial pectinolytic enzymes. Open Biotechnol J 2009;3:9-18.

45. Al-Najada AR, Al-Hindi RR, Mohamed SA. Characterization of polygalacturonases from fruit spoilage Fusarium oxysporum and Aspergillus tubingensis. Afr J Biotechnol 2012;11:8527-36.

46. Thakur BR, Singh RK, Handa AK. Chemistry and uses of pectin--a review. Crit Rev Food Sci Nutr 1997;37:47-73.

47. Hobbs HR, Thomas NR. Biocatalysis in supercritical fluids, in fluorous solvents, and under solvent-free conditions. Chem Rev 2007;107:2786.
48. Merin MG, Martin MC, Rantsior K, Cocolin L, Morata de Ambrosini VI. Characterization of pectinase activity for enology from yeasts occurring in argentine bonarda grape. Braz J Microbiol 2015;46:815-23.

49. Chen WC, Hsieh HJ, Tseng TE. Purification and characterization of a pectin lyase from Pythium splendens infected cucumber fruits. Bot Bull Acad Sin 1998;39:181-6.

50. Yadav S, Shastri NV. Partial purification and characterization of a pectin lyase produced by Penicillium oxalicum in solid-state fermentation (SSF). Indian J Biotechnol 2005;4:501-5.0

How to cite this article:

Okonji RE, Itakorode BO, Ovumedia JO, Adedeji OS. Purification and biochemical characterization of pectinase produced by Aspergillus fumigatus isolated from soil of decomposing plant materials. J App Biol Biotech. 2019;7(03):1-8. DOI: 10.7324/JABB.2019.70301 